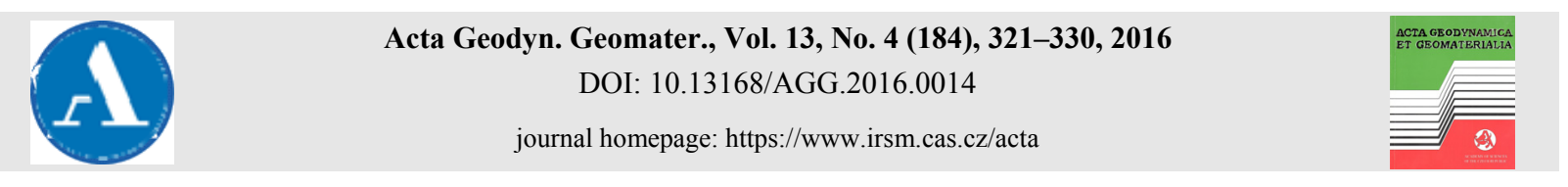

ORIGINAL PAPER

\title{
THE IMPACT OF DEEP UNDERGROUND COAL MINING ON EARTH FISSURE OCCURRENCE
}

\author{
Agnieszka A. MALINOWSKA * and Ryszard HEJMANOWSKI
}

AGH University of Science and Technology, Faculty of Mining Surveying and Environmental Engineering, Department of Mining Areas Protection, Geoinformatics and Mining Surveying, Al. A. Mickiewicza 30, 30-059 Kraków, Poland

Corresponding author's e-mail: amalin@agh.edu.pl

\section{ARTICLE INFO}

Article history:

Received 9 March 2016

Accepted 18 April 2016

Available online 13 June 2016

Keywords:

Earth fissure

Risk assessment

Horizontal strain

Underground coal mining

\section{ABSTRACT}

Deep underground mining commonly causes land subsidence and mining tremors. The occurrence of Earth fissures induced by deep underground mining operations is a rare phenomenon. The development of Earth fissures is a rapid and unexpected process causing a particular hazard to the developed areas. The presented research focuses on the investigation of Earth fissure propagation in the light of geotechnical and geological condition. The presented approach can be used for establishing most significant risk factors influencing Earth fissure development in the areas induced by deep mining.

\section{INTRODUCTION}

Deformations of rock mass which cause discontinuities on the surface are usually accompanied by high stress zones of geological origin or are the result of mining activities (Cmiel, 2012; Jochymczyk et al., 2006). Technical literature describes many of these types of transformation (Bateson et al., 2015; Blachowski and Ellefmo, 2012; Gao et al., 2012; Grün, 1995; Kowalski, 2005; Lee et al., 1996; Li et al., 2009; Liu et al., 2015; Kuznetsov and Trofimov, 1992; Sroka, 2008). Earth fissures occurs unexpectedly and may create hazard to infrastructure and developed areas These hazards are much more difficult to predict than continuous deformations therefore it is very important to describe their causes and analyze the risk factors. The main hazard associated with the formation of discontionous deformations is the small depth of mining and the remains of shallow, historical coal basins. They can be found in old coal mining regions, coal bed outcrop areas, and in areas of shallow mining of zinc, and lead, iron ore, rock salt, etc.

In the deep mining areas discontinuities occur much less frequently (Grün, 1995; Sroka, 2008). This phenomenon has been relatively poorly investigated and rarely reported in the deep-seated deposits. The discontinuous deformation frequently reaches deep mining areas and no sufficient information is available on the surface displacement measurements, details of geological structure of the rock mass, and timing of fissure or threshold occurrence. This limits the possibilities for separating relevant factors and their analysis. The only work containing large amount of data is a study by Grün (Grün, 1995), who made an attempt at capturing statistical causes of fissures formation in the Ruhr basin.

A relatively detailed analysis was performed in this paper on the basis of available data. The performed study can be used for developing a procedural algorithm for this type of analysis. It shed light on the significance of the individual factors which could have been the cause of the fissures formation.

\section{STUDY AREA}

Studies were carried out in the mining area of one of the Polish underground, hard coal mines. Extraction in that area has been a subject of analyses carried out since 2000.

\subsection{STRATIGRAPHY AND LITHOLOGICAL SETTING}

The discussed area is part of one of the European coal mining basins. The most thoroughly examined part of the deposit is the central region covering an area of approximately $250 \mathrm{~km}^{2}$. Carboniferous sediments forming the coal bed are dominated by Lublin's Westphalian strata and younger Westphalian cells. These layers are deposited directly below the 


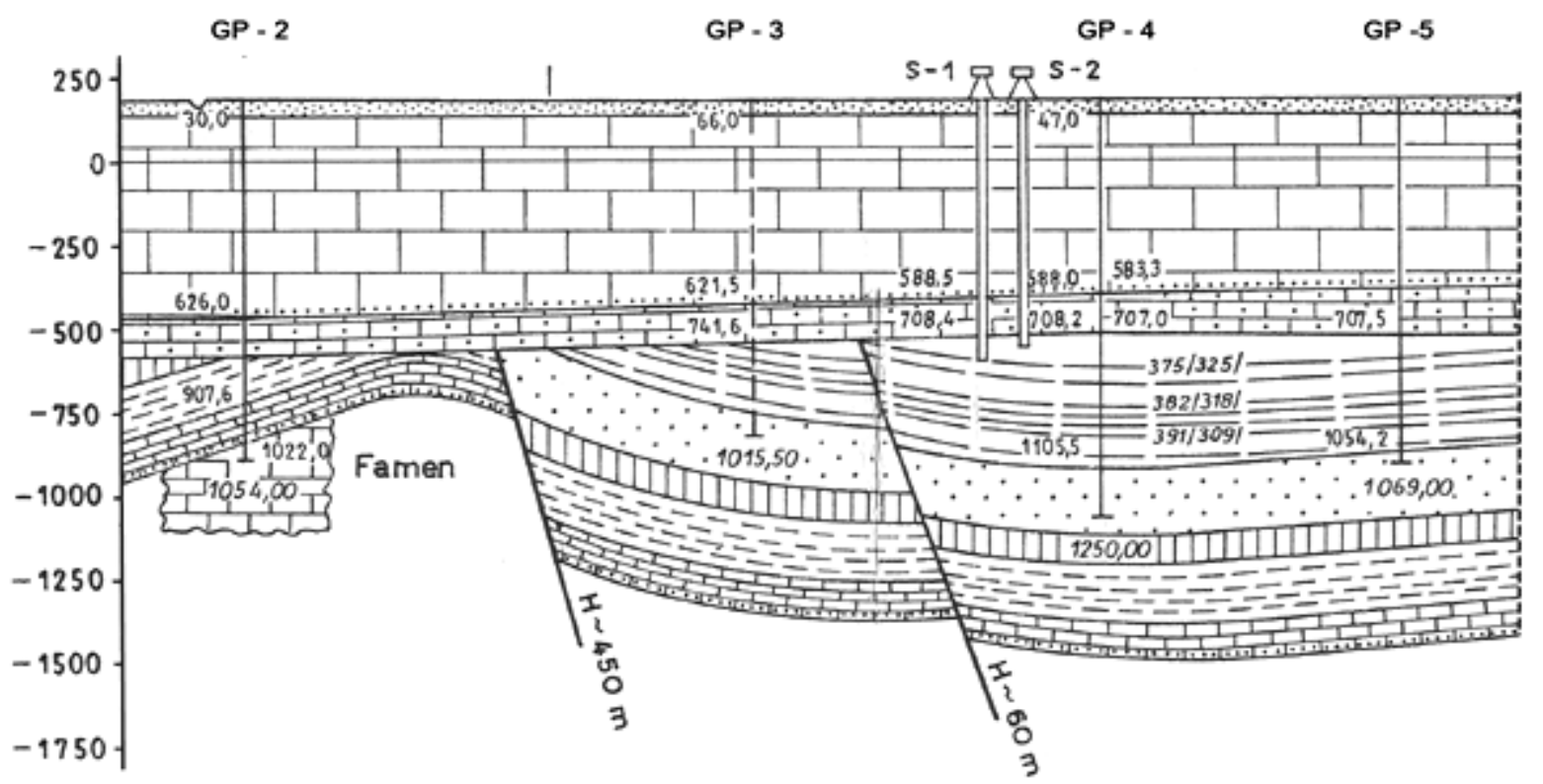

Fig. 1 Geological Cross-Section (Pokrzycki et al., 1974).

Mesozoic-Cenozoic overburden. The thickness of Lublin's layers fluctuate around 35 to $460 \mathrm{~m}$, with the predominance of mudstone-clay stone sediments. The central coal region is located within the two large tectonic units. The north-eastern section is located on the Lukow-Hrubieszow elevation, while southwestern section of CRW is located within the Lublin Graben.

The deposit in the central region is criss-crossed by numerous fault lines, intersecting deposits in the south-western and north-eastern direction. The amplitudes of the stratigraphic throw range from 5 to 80 meters. In study area there was one significant fault located with the throw of $450 \mathrm{~m}$ (Fig. 1).

The study area contained 13 geological holes, based on which the spatial arrangement of geological layers system was made. The carbon layer is overlain by Mesozoic-Cenozoic strata, mainly consisting of chalk and marl. The thickness of these layers varies from 600 to $720 \mathrm{~m}$. The sub-surface layer of soil is composed mainly of clay, silt, and varied granularity sand. Clay dominates at the western border of the mining area, while the northern part is dominated by sands.

\subsection{MINING}

Extraction (mining operations) in the area was conducted using the longwall caving method. The average speed of extraction in the area ranged from 860 to $900 \mathrm{~m}$ and the extraction thickness amounted to an average of 1.8 to $2.5 \mathrm{~m}$. Extraction was conducted in two coal seams lying horizontally. The average extraction rate was about 5-6 $\mathrm{m} /$ day. Extraction in study area was conducted in the period 2002-2010 (Fig. 2).

\subsection{EARTH FISSURE}

In the area subjected to the impact of underground mining operations, four zones were separated, where Earth fissures of land surface were observed (Fig. 2).

Two zones were located at the northern border of the mining area. The first fissures began to appear on the surface in November 2006 (zone 2). These fissures were observed on the farmland, and they ran parallel to the direction of extraction in this area. The length of individual fissures was about $250 \mathrm{~m}$ while the width of the fissures ranged from $2 \mathrm{~cm}$ to $8 \mathrm{~cm}$ (Fig. 2, Fig. 3a). In many places it was impossible to determine what their actual width is. At the northern border of the mining area another fissure was formed in January 2007. Its length reached 680 meters and width about $5 \mathrm{~cm}$ (Fig. 2, Fig. 3b). The depth of fissures in the second zone was difficult to determine. In October 2010, north of the border of the mining area another discontinuous deformation of 500 meters long and width $5 \mathrm{~cm}$ has appeared (zone 1, Fig. 2). Two other zones were located at the western border of the mining area. In January 2005 three fissures were observed, which ran in a north-south direction, their length ranged from 150 to $180 \mathrm{~m}$, and their width reached $6 \mathrm{~cm}$ (Fig. 2, Fig. 4). Fissures were located approximately 100 meters from the edge of the extraction field. The fissure appeared in a developed area, causing significant structural damage to buildings located within. The last area in which the fissures were observed was located near the southwest area (zone 4, Fig. 2). The fissure generated in 2008 was $580 \mathrm{~m}$ long and $7 \mathrm{~cm}$ wide (Fig. 3c).

Earth fissures occurred in an area of $19 \mathrm{~km}^{2}$, in four zones. In light of these observations an attempt 


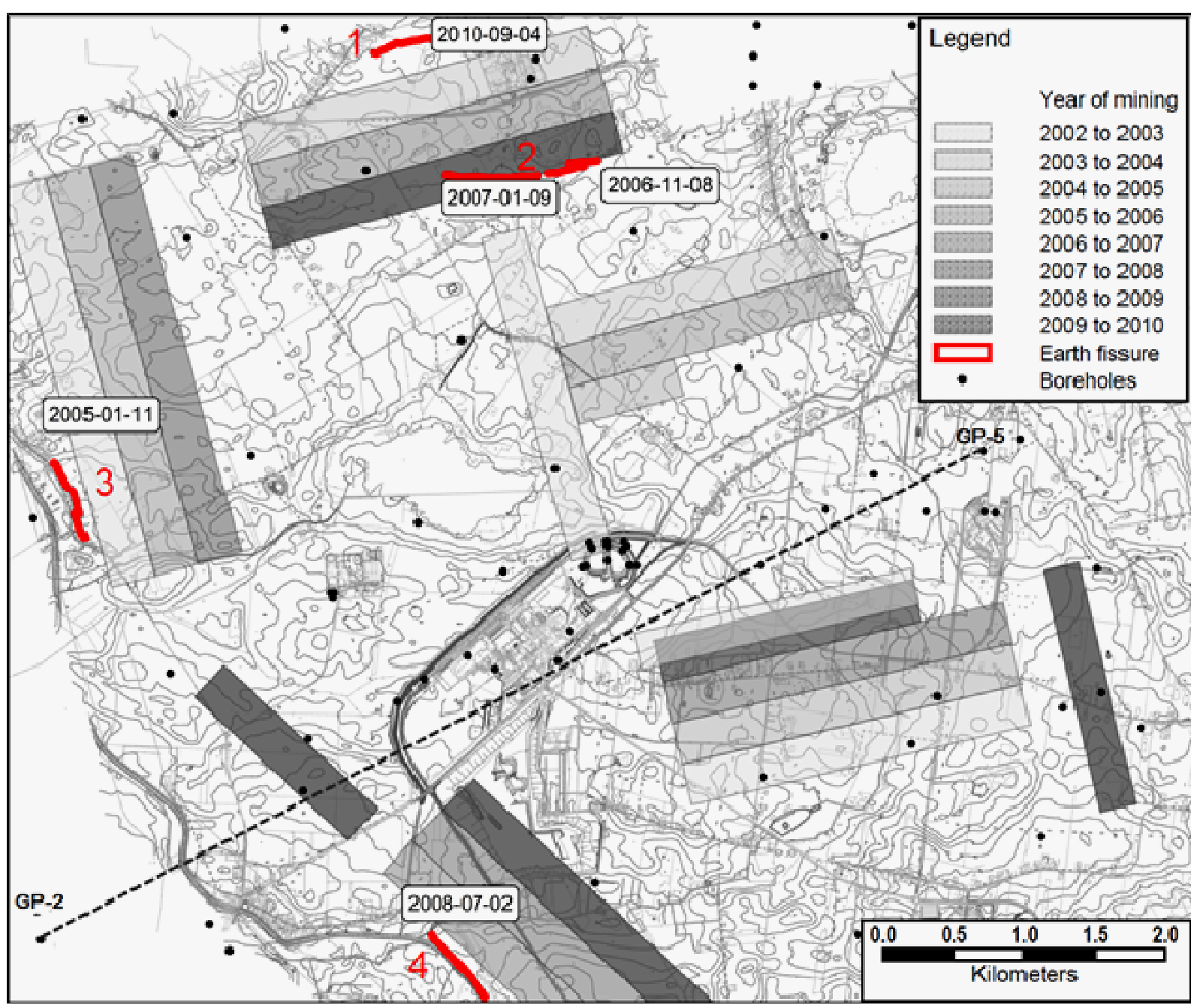

Fig. 2 Positions of occurrence of discontinuous deformations.

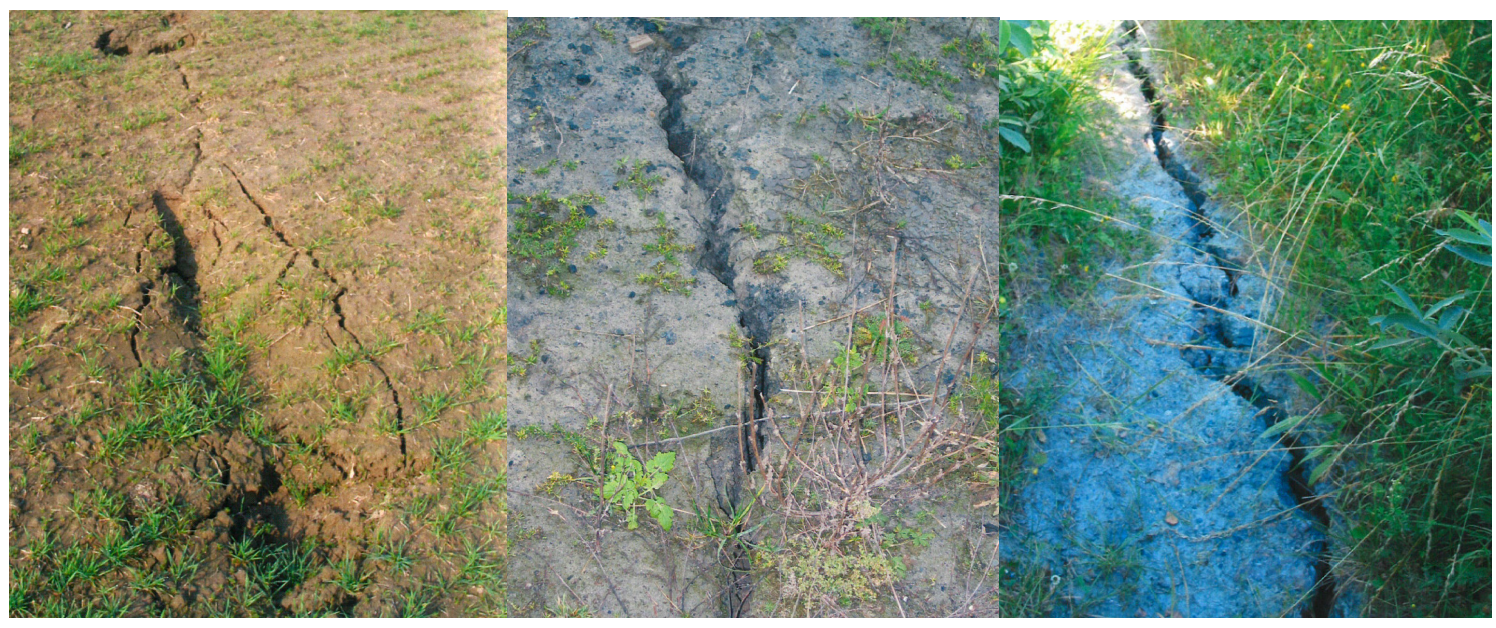

a)

b)

c)

Fig. 3 Fissures that have occurred on the surface sequentially in zones 1, 2 and 4. 

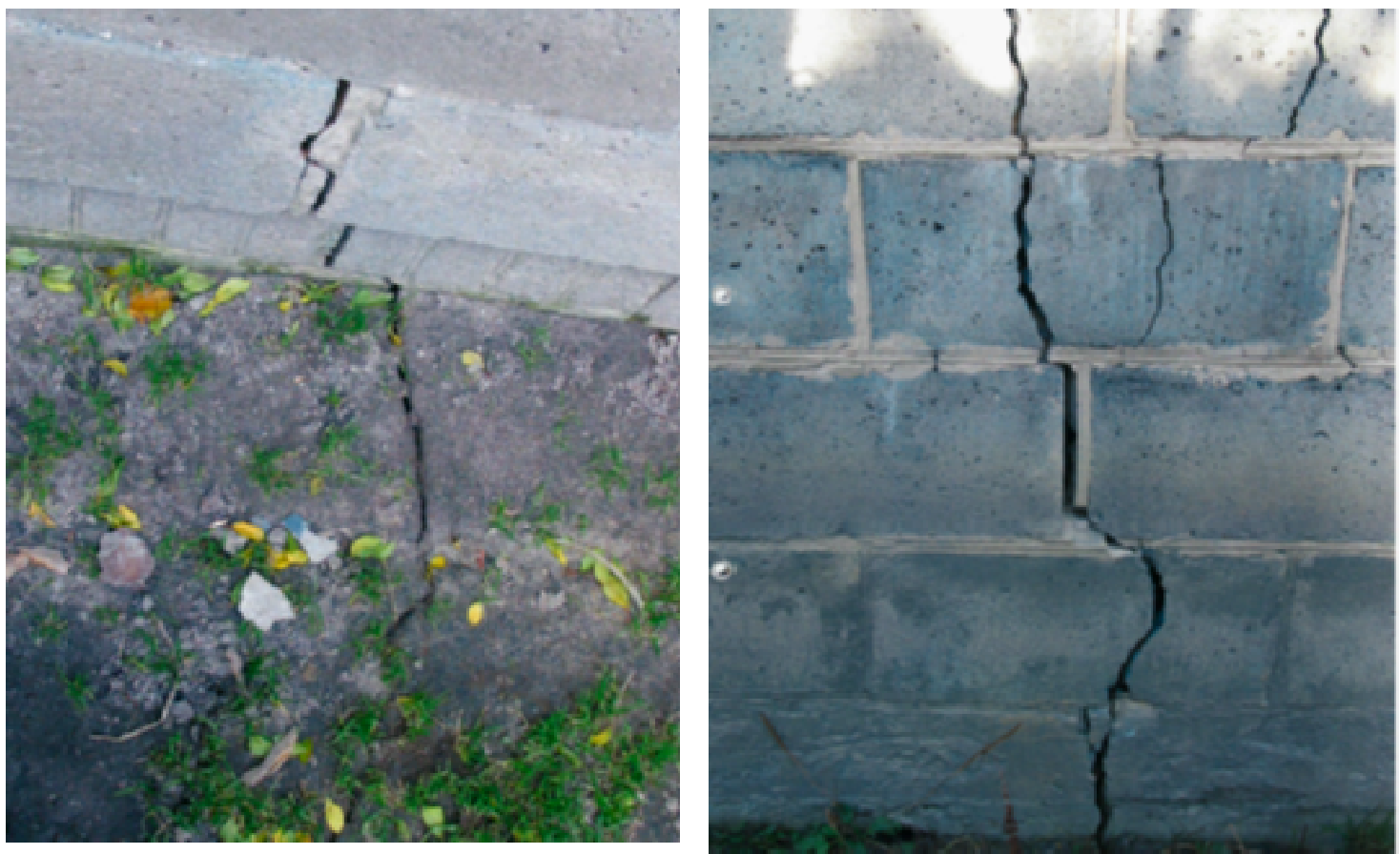

Fig. 4 Fissures that have occurred on the surface sequentially in zone 3.

was undertaken to analyse the geological and mining factors which may have contributed to the formation of Earth fissures on the surface.

\section{DISTRIBUTION OF STRESSES IN THE MINE AREA}

So far the most common criterion taken into account when analysing the risk of discontinuous ground surface deformations was the depth of the seam and void geometry. In the case of discontinuous deformations of a linear type formed above mining areas where production is realized at a considerable depth, it is necessary to conduct in-depth analysis of additional mining - geological factors. It was concluded that the process of formation of the discontinuous phenomenon on the land surface may be affected by additional factors such as:

- tectonics,

- type of overburden and stratum layers above extracted seam,

- $\quad$ status of stresses generated by extraction.

Based on the available data a cause and effect analysis was carried out for the spatial distribution of these factors and the places where Earth fissures appeared.

\subsection{TECTONICS}

One large fault was in the study area; its layer direction azimuth was about $135\left[^{\circ}\right]$, and throw amplitude was about $450 \mathrm{~m}$ (Fig. 1 fault is located between GP-2 and GP-3 boreholes). The angle of dip of the layer is approx. $70\left[^{\circ}\right]$, and its dip azimuth $45\left[^{\circ}\right]$ (Fig. 5).
This fault in the horizontal projection was located at a distance of $280 \mathrm{~m}$ from the fissure in zone 3 , and $700 \mathrm{~m}$ from the fissures in the zone 4 .

The fault had not had any direct contact with surface area, and its outcrop was lying at a depth of about 550 meters below the surface. The minimum distance between the edge of the operated walls and the fault in zone 3 was $500 \mathrm{~m}$. However, in zone 4, this distance was shorter and amounted to $340 \mathrm{~m}$ (Fig. 6). The fault outcrop was so deep that the extraction operations conducted in the area had no effect on its activation. Therefore, it must be presumed that the Earth fissures observed in zones 3 and 4 were not initiated by the fault dislocations.

\subsection{LITHOSTRATIGRAPHY OF SUPERIMPOSED STRATA LAYERS ABOVE CARBONIFEROUS FORMATION}

The following layers of the analyzed area that may affect the process of the formation of Earth fissures on the land surface were split into different categories:

- geology of overburden, with particular attention paid to the presence of units susceptible to the influence of water (clay and silt layers) and solid mass,

- geology of layers lying above carbon layers, characterized by high stiffness.

Based on information gained from 13 boreholes, an attempt was made to determine the spatial distribution of shallow and deep geological layers (Fig. 7). 


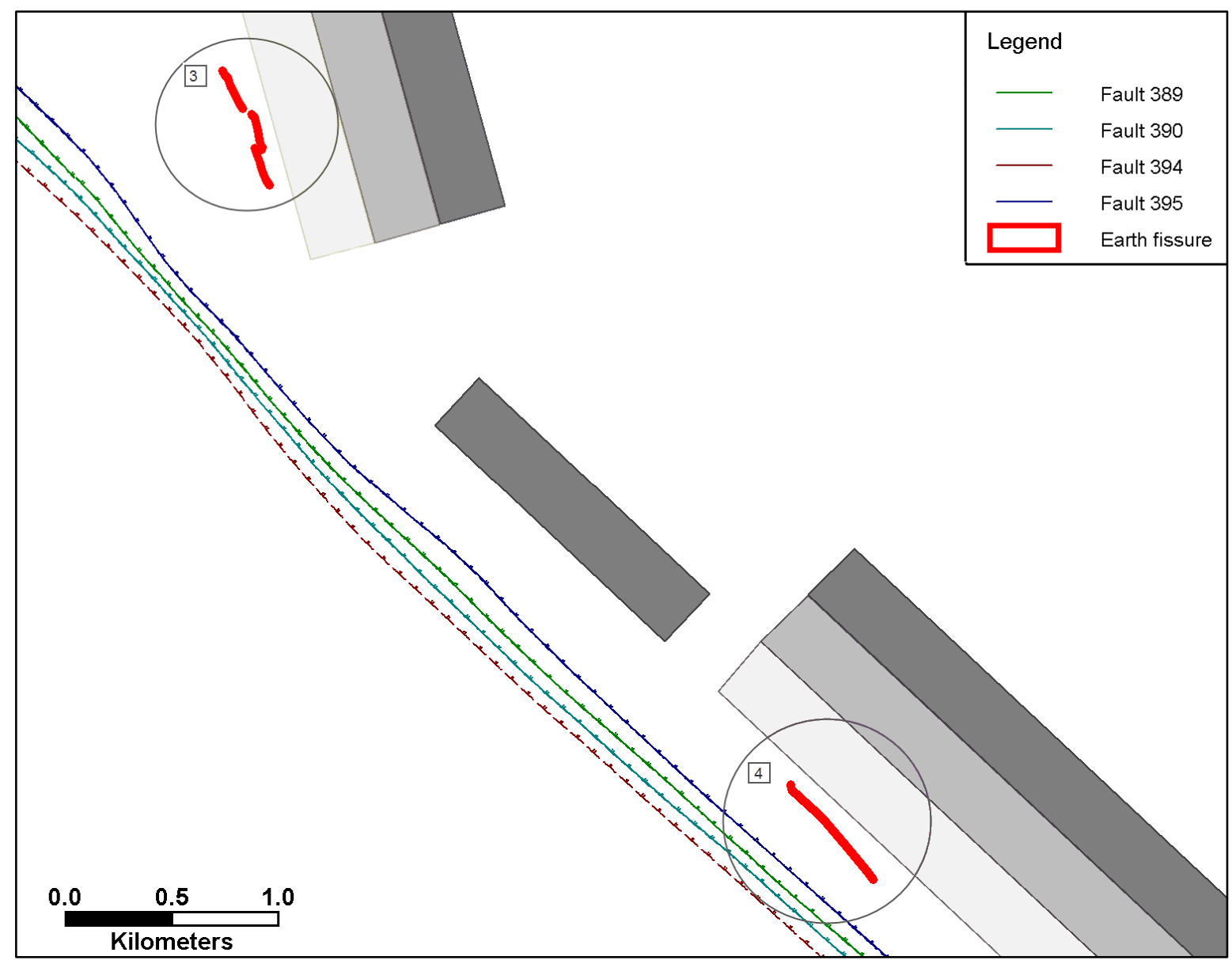

Fig. 5 Fault outcrops in the area where fissures have appeared.

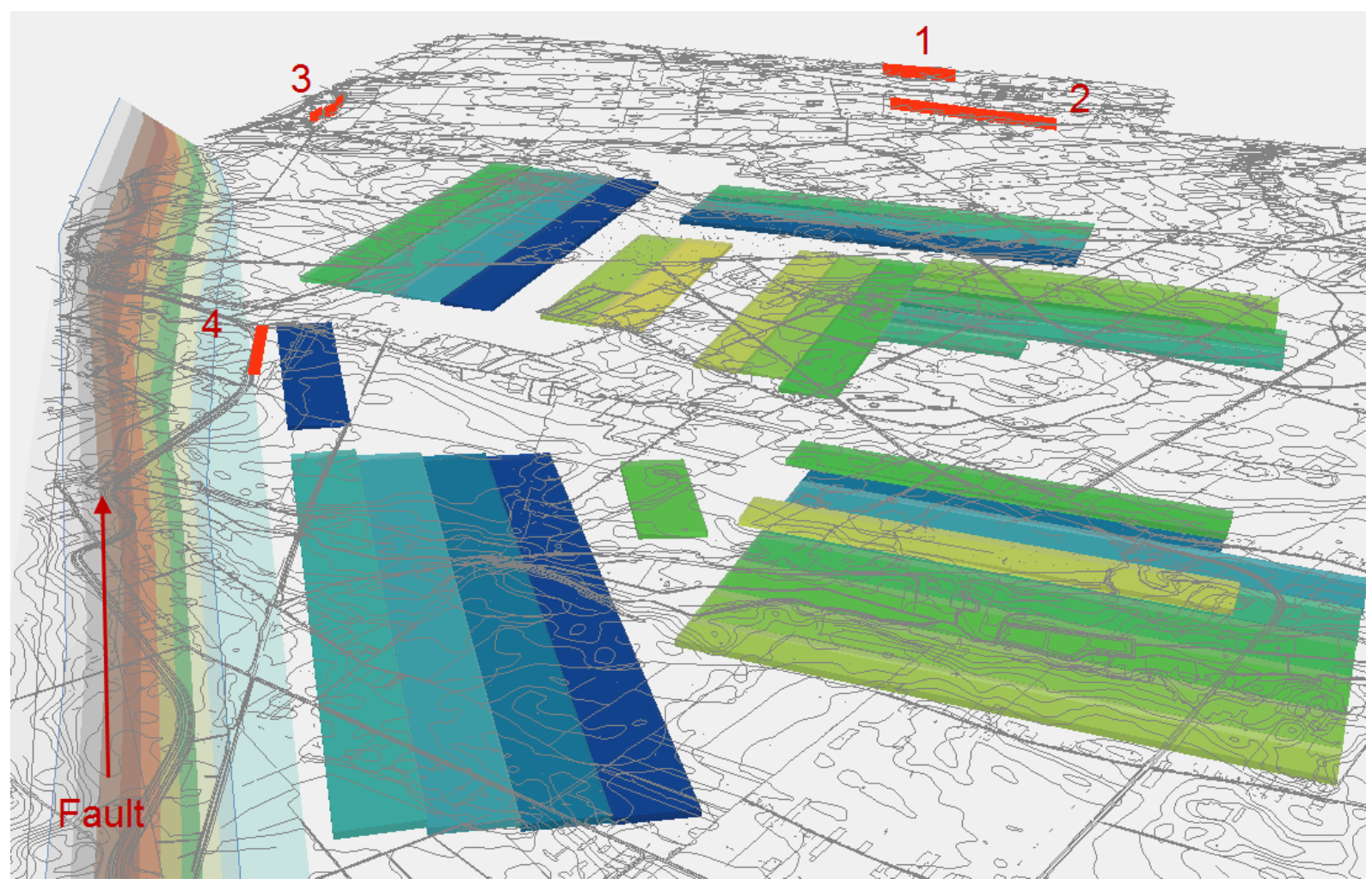

Fig. 6 Spatial distribution of the fault. 


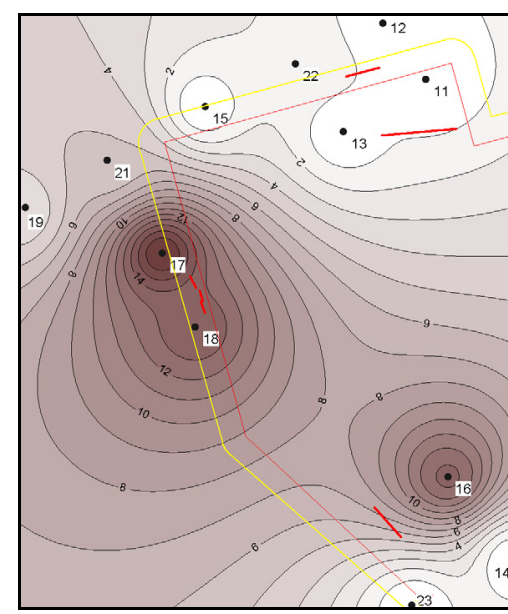

a)

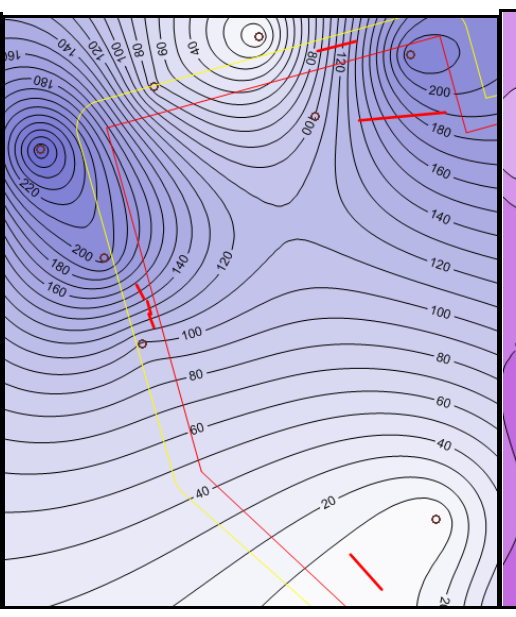

b)

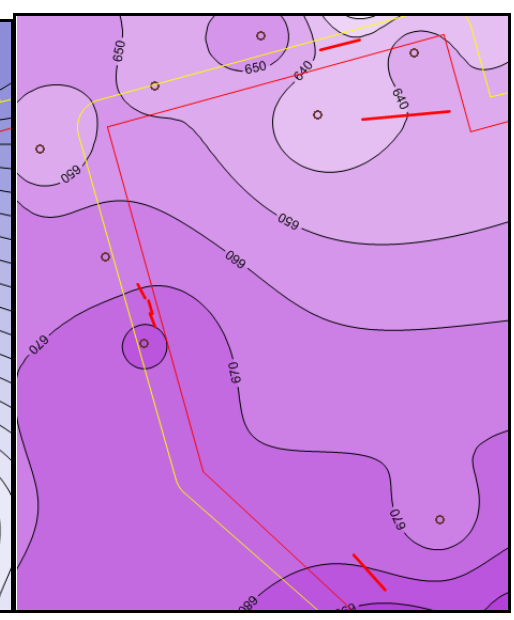

c)

Fig. 7 The thickness of clay and silt layers, in meters a), the thickness of marl located at small depths b), the thickness of Cretaceous formations c).

The shallowest Quaternary strata were made of clay, silt and sand. In zones 1 and 2, layers of subsurface soil were built mainly of light grey sands, varying in granularity, in places with a touch of gravel. The thickness of sand reached up to $50 \mathrm{~m}$. Sand layers forming the overburden in the northern part of the mining area were progressively disappearing in its western part, then to transform into loam and sands and subsequently into clay and silt layers. In the area of zones 3 and 4 the sub-surface layer of soil was built mainly of clay, and greenish grey, dark grey dusty silts. The thickness of these formations reached up 17 meters (zone 3, Fig. 7a). In region 4, the clay formations thickness ranged from 6 to $8 \mathrm{~m}$. The Cretaceous formations created by the thick layers of carbonate rocks underlied the Quaternary strata. The shallowest layers of the Cretaceous formations were built mostly of grey marl. Marl thickness varied from $0 \mathrm{~m}$ to $180 \mathrm{~m}$ in the fourth zone (Fig. 7b). In places where the grey marl formations disappeared, the layers of marl limestone and Cretaceous came directly to the Quaternary formations. The total thickness of carbonate rocks oscillated between 600 and $720 \mathrm{~m}$ (Fig. 7c).

Discontinuous deformations were generated in areas where the overburden was built of both plastic formations (zones 1,2) and solid formations (zones 3, 4). It can be assumed that the process of generation of discontinuous deformation on the surface was influenced by a significant thickness of clay and silt formations located in the area of zone 3 . In the case of other areas, the relationship between lithostratigraphy of the remaining layers and the process of the formation of Earth fissures cannot be confirmed.

\subsection{STRESSES ON THE SURFACE CAUSED BY MINING OPERATIONS}

Land subsidence measurements were carried out only in zone 3 of the analyzed area. On this basis it was possible to set the parameters of the influence function model, which was applied to predict the land surface deformation. The Knothe model was used in the calculations (Knothe, 1954). Sequentially based on model parameterized to local conditions, the simulation of continuous deformations, which appeared on the surface of the four zones was performed. Continuous deformations of the land surface caused by the impact of underground mining are characterized by deformation indicators. Among them are, e.g. horizontal strainswhich describe the state of stresses in the rock mass. The Earth fissures that appeared on the surface could have been generated by tensile stresses, therefore the studies focused on the analysis of maximum and directional horizontal strains, as well as the dynamics of their appearance on the ground surface.

\section{a) Directional Strains Perpendicular to the Earth Fissure Plane}

Spatial distribution of horizontal directional strains, which had an impact on the ground surface in a function of time in the four analysed areas, was defined for each Earth fissure. The path of the strains was analysed perpendicular to the Earth fissures plane. The distribution of this indicator ata selected point of the Earth fissure is presented in graphs (Fig. 8).

The correlation between the distribution of horizontal strains over time, and the inconsistent occurrence of the discontinuous deformations, can be only observed in the third and fourth zone (Figs. 8c and $8 \mathrm{~d})$ ), when the directional horizontal strains reaching a value of about $2.0 \mathrm{~mm} / \mathrm{m}$ have occurred on the surface.

\section{b) Maximum Tensile Strains in Surface Terms}

The field of deformation on the ground surface was related to the expanding field of mining operations. In each area, mining operations were carried out on pristine rock mass, affecting its balance for the first time. The stresses in the upper layers, when mining operations were carried out for the first 

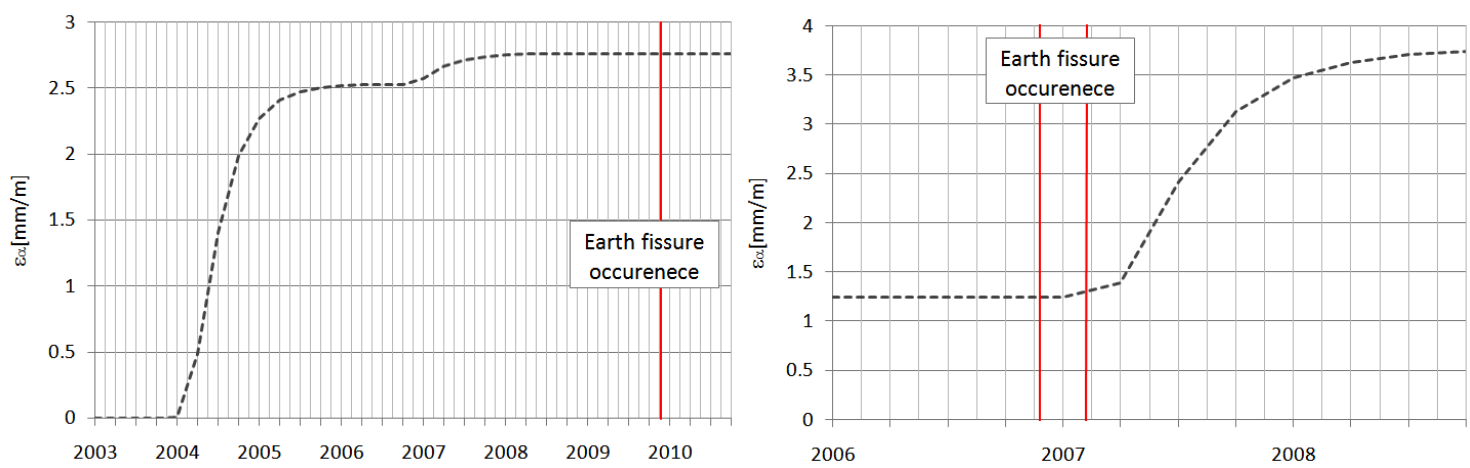

a) zone 1

b) zone 2
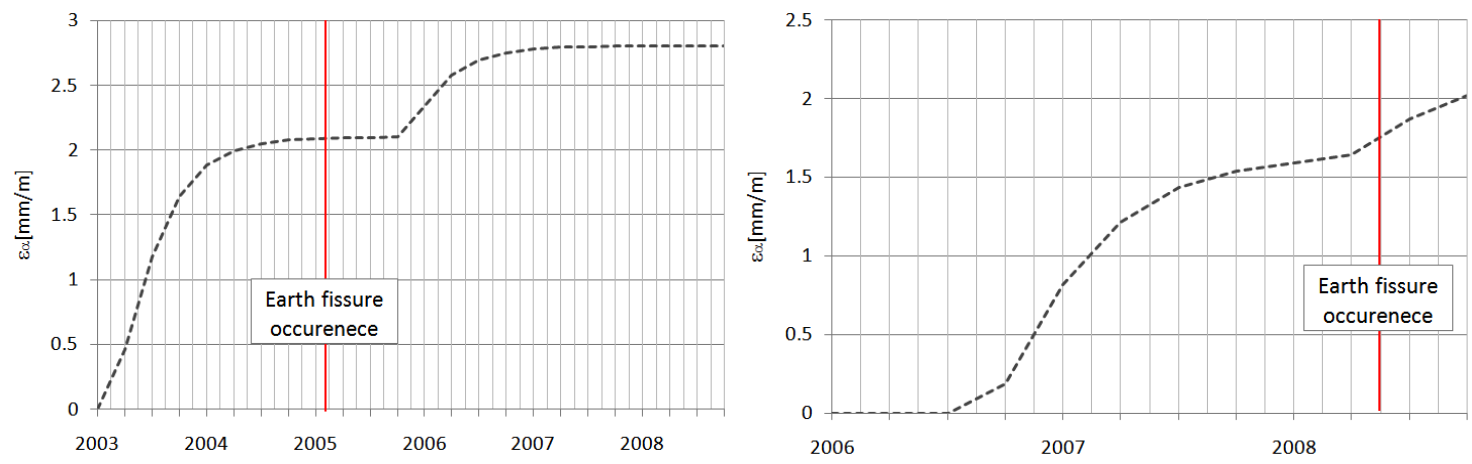

c) zone 3

d) zone 4

Fig. 8 Distribution of horizontal strains perpendicular to the Earth fissure plane.

time, are much higher than in the case of a rock affected by earlier mining activities. Based on the projections of horizontal strains, it was possible to trace the process of the horizontal strains formation on the ground surface. The forecast was made in quarterly intervals. For the needs of the analysis, the maps of maximum tensile strains which occurred on the surface in the period 2002- 2010 were used.

In the first zone area, mining operations were carried out south of this zone. Extraction from the walls was conducted from east to west. Tensile strains which occurred to the north of the operation field amounted to a maximum of $2.8 \mathrm{~mm} / \mathrm{m}$. In the area where the Earth fissure was observed the horizontal strains were the most significant (Fig. 9). The second zone is located south of the lots used for mining. Mining operations were carried out in south-westerly direction. Maximum horizontal strains that occurred in this region amounted to $3.6 \mathrm{~mm} / \mathrm{m}$.

Mining operations in the area of the third zone were carried out from north to south (Fig. 10a). The maximum tension which occurred on the ground surface initiated the formation of discontinuous deformation. Tensile strains in the area reached a maximum of $2.8 \mathrm{~mm} / \mathrm{m}$. In the fourth region mining was conducted from north-west to south-east (Fig. 10b). Discontinuous deformation of the linear type was initiated by tensile strains of $2.0 \mathrm{~mm} / \mathrm{m}$.
The impact of the speed of occurrence of horizontal strains on the surface was also assessed. Obtained results confirmed a spatial correlation between the zones where the dynamics of strains occurrence was the greatest and places where Earth fissures emerged (Fig. 11). The monthly increase in horizontal strains at which Earth fissures appeared on the surface ranges from 0.20 to $0.36 \mathrm{~mm} / \mathrm{m}$ per month.

\section{RESULTS AND DISCUSSION}

The study allowed for answering the question of what factors play a decisive role in the formation of Earth fissures on the ground surface in the area subjected to the influence of deep underground coal mining. The factors that determined the formation of Earth fissures in the presented case were as follows:

- Horizontal strains of tensile type, with values greater than $2.5 \mathrm{~mm} / \mathrm{m}$;

- The land built of clay layer of considerable thickness;

- A significant thickness of marl layers of in the overburden;

- No prior impact on rock mass by mining activities.

It seems that one of the deciding factors was the fact that mining was conducted in a pristine rock mass. No previous stress relief in the rock mass could 


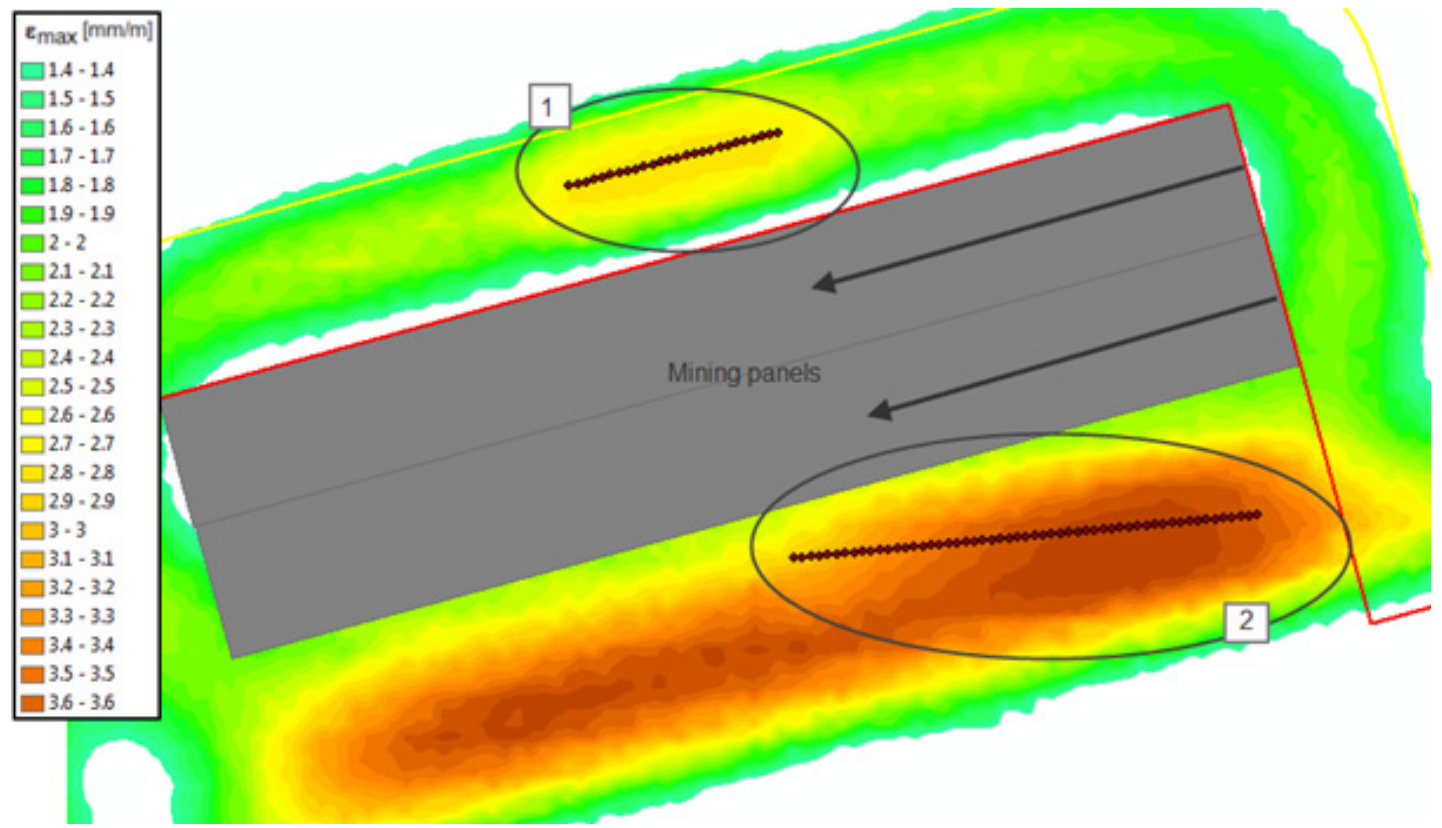

Fig. 9 Distribution of the maximum horizontal tensile strains in the period 2002-2010 (zones 1, 2).

\begin{tabular}{|l|}
\hline$\varepsilon_{\max }[\mathrm{mm} / \mathrm{m}]$ \\
$\square 1.4-1.4$ \\
$\square 1.5-1.5$ \\
$\square 1.6-1.6$ \\
$\square 1.7-1.7$ \\
$1.8-1.8$ \\
$\square 1.9-1.9$ \\
$\square 2-2$ \\
$\square 2.1-2.1$ \\
$\square 2.2-2.2$ \\
$\square 2.3-2.3$ \\
$\square 2.4-2.4$ \\
$\square 2.5-2.5$ \\
$\square 2.6-2.6$ \\
$\square 2.7-2.7$ \\
$\square 2.8-2.8$ \\
$\square 2.9-2.9$ \\
$\square 3-3$ \\
$\square 3.1-3.1$ \\
$\square 3.2-3.2$ \\
$\square 3.3-3.3$ \\
$\square 3.4-3.4$ \\
$\square 3.5-3.5$ \\
$\square 3.6-3.6$ \\
\hline
\end{tabular}

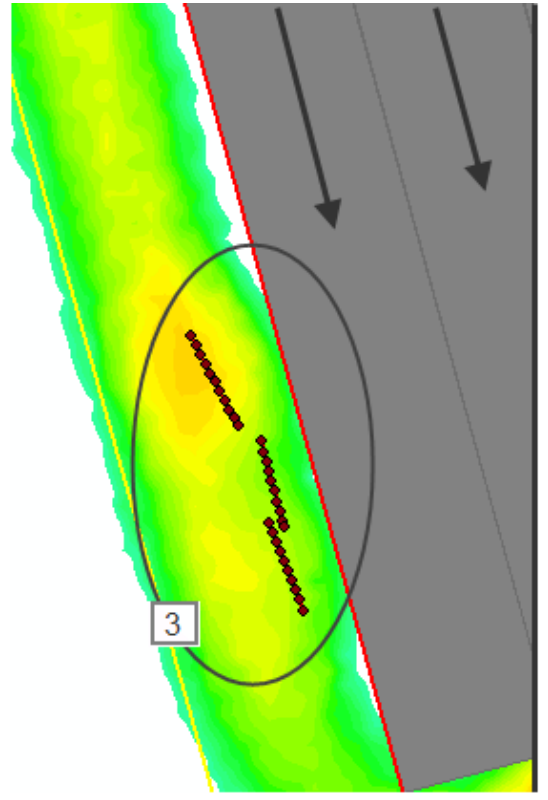

a)

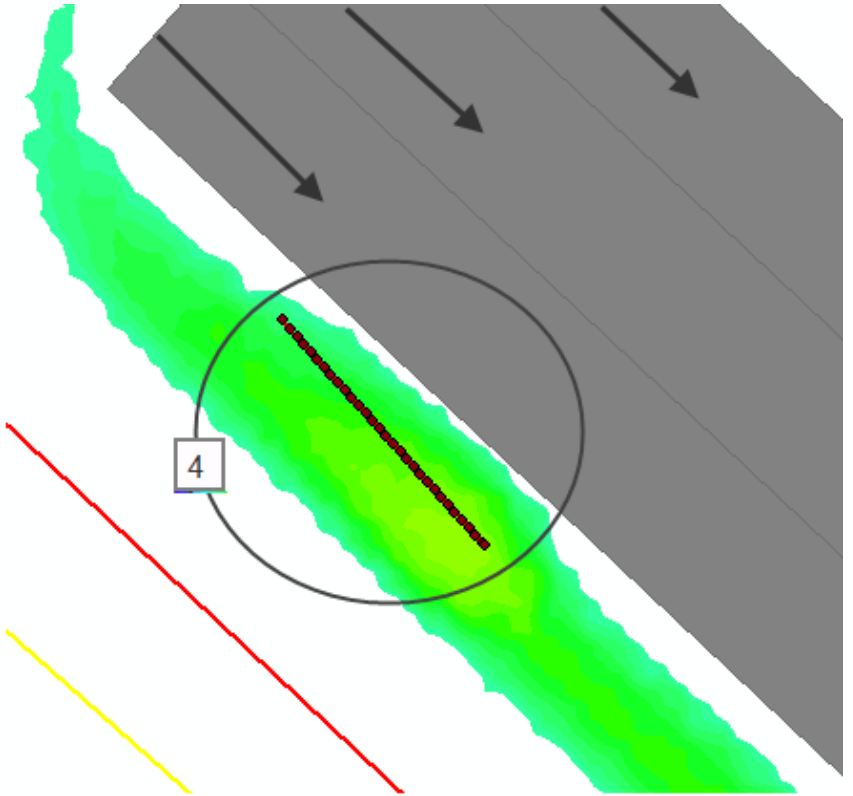

b)

Fig. 10 Distribution of the maximum horizontal tensile strains in the period 2002-2010 (zones 3, 4).

contribute to the formation of Earth fissures with significant tensile forces. It appears that not only the existence of appropriate field of tensile strains, but also the geotechnical conditions in shallow soil layers determine - in the case of extractions carried out in a single coal seam - the occurrence of surface Earth fissures. The analysis of factors does not give a universal message, and the presented methodology can be used in other areas where the threat of discontinuous deformation of the linear type exists.

Based on the results of this study, the following spatial - attribute analysis algorithm can be proposed to determine the potential risk in the form of Earth fissure occurrence on the surface. The first step should lie in defining logical variables for the following attributes (conceptual categories):

- no earlier impact from extracting other reserves / deposits in the given area exists? (truth / false)

- the extraction rate greater than $5 \mathrm{~m} /$ day? (truth / false)

- the size of the extraction field similar or slightly greater than $80 \%$ of the radius of the main impacts? (truth / false). 


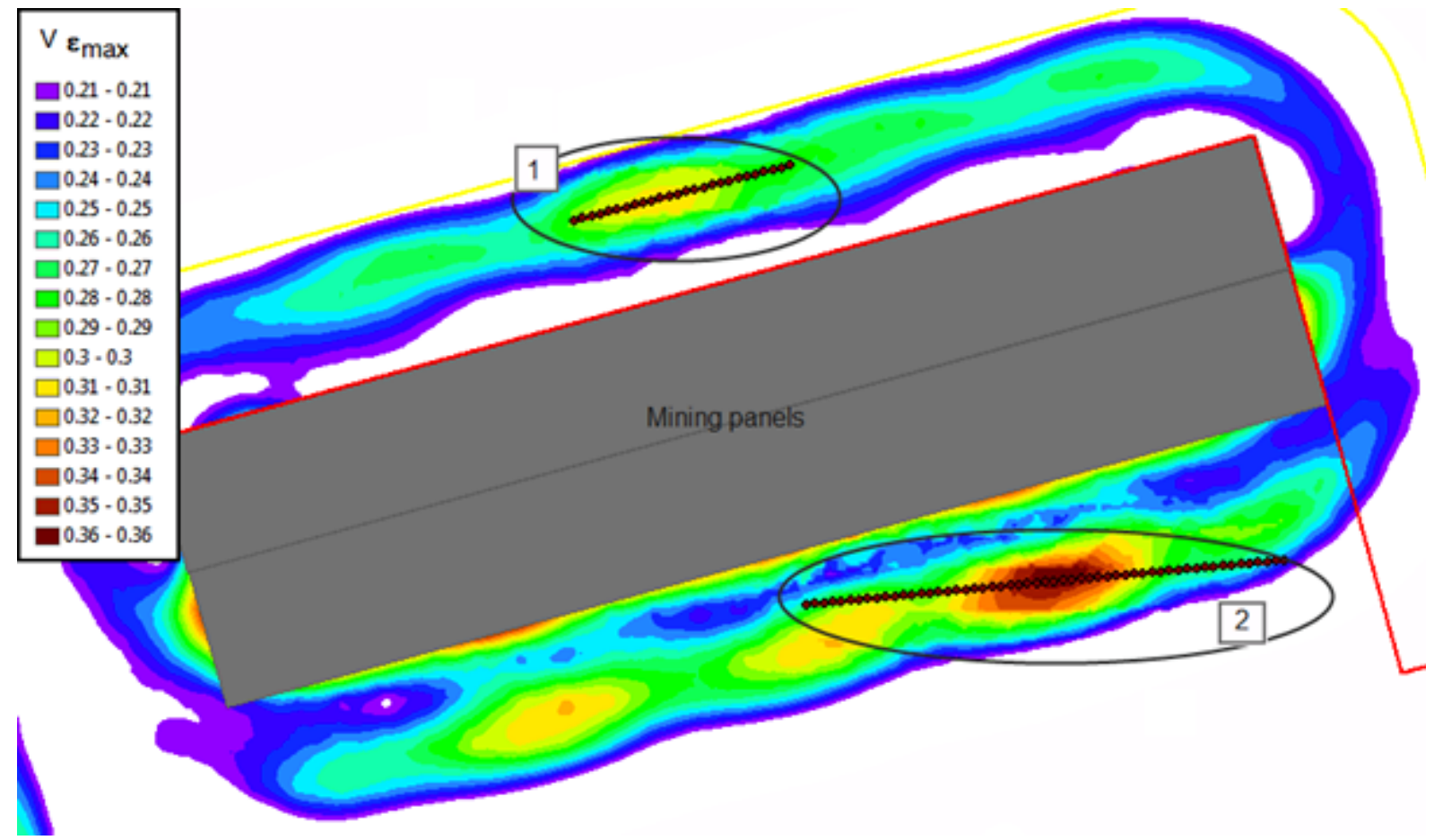

a)

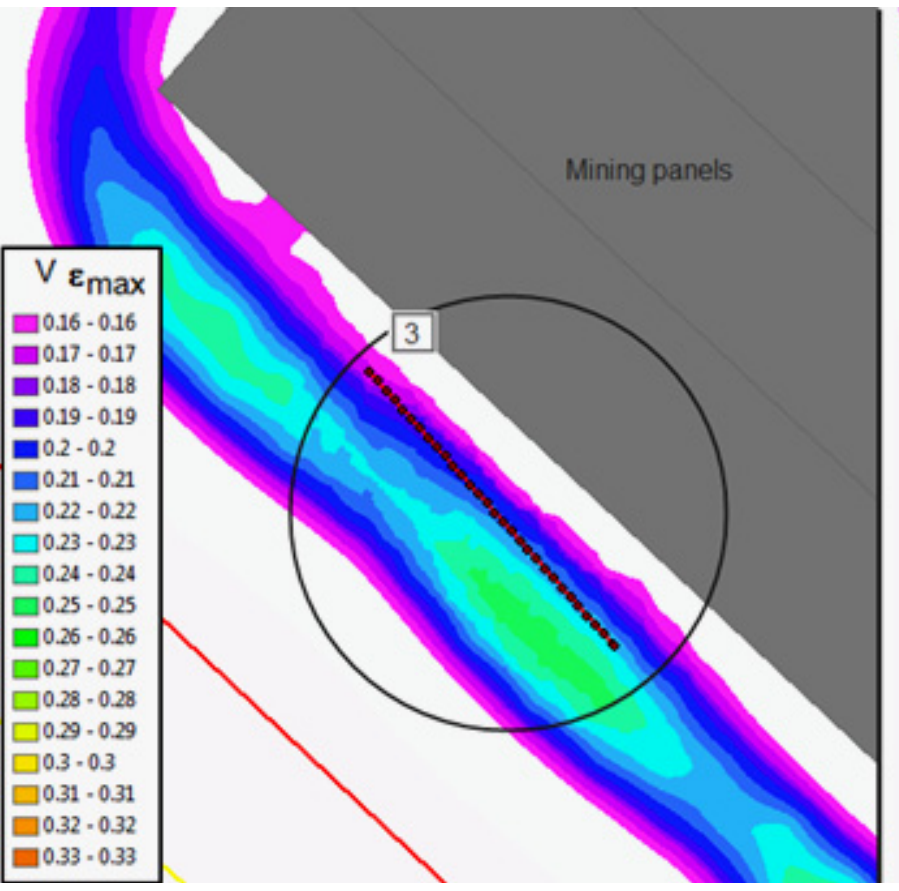

b)

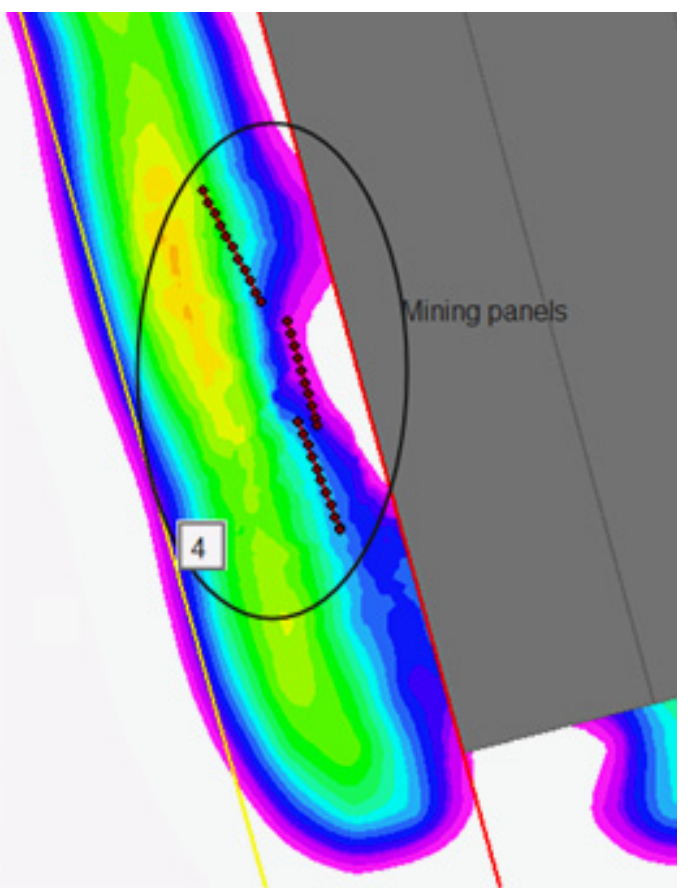

c)

Fig. 11 Distribution of the speed of change of the maximum horizontal tensile strains in the period 2002-2010, $\mathrm{mm} / \mathrm{m}$ per month (zones $1,2 \mathrm{a}$ ); zone $3, \mathrm{~b}$ ); zone $4 \mathrm{c})$ ).

In the case of positive answers to all above questions, the layers of marl of significant thickness (tens of meters) in the overburden, and layers of clay with a thickness of 2-6 $\mathrm{m}$ in the ground should be examined. If such conditions exist, there is a high probability of occurrence of Earth fissures or thresholds in maximum strains zones extending along the course of the longwall coal caving.

The proposed algorithm will be tested in other coal basins. 


\section{ACKNOWLEDGEMENTS}

Research project funded by the Polish National Science Center (NCN), grant No.UMO2014/15/B/ST10/04892

\section{REFERENCES.}

Bateson, L., Cigna, F., Boon, D. and Sowter, A.: 2015, The application of the Intermittent SBAS (ISBAS) InSAR method to the South Wales Coalfield UK. International Journal of Applied Earth Observation and Geoinformation, 34, 249-257. DOI: 10.1016/j.jag.2014.08.018

Blachowski, J. and Ellefmo, S.: 2012, Numerical modeling of rock mass deformation in sublevel caving system. Acta Geodyn. Geomater., 9, 3 (167), 379-388.

Cabala, J., Teper, L. and Rutkowski, T.:2004, Rockmass deformations caused by zinc and lead ores mining in Olkusz Region (Southern Poland). Acta Geodyn. Geomater., 1, 1(133), 47-58.

Cmiel, S. R.: 2012, The Upper Silesian coal basin fault zone as a region of high-risk operation. Acta Geodyn. Geomater., 9, 2 (166), 133-136.

Gao, F., Xingguang, L., Chaofeng, G. and Hongmei, Ch.: 2012, Numerical simulation and damage analysis of fissure field evolution law in a single coal seam mining. International Journal of Mining Science and Technology, 22, 6, 863-866.

Grün, E.: 1995, Analyse und Prognose von Unstetigkeiten als Folge Bergbaubedinger Bodenbewegungen im linksrheinischen Steinkohlengebiet. PhD Thesis, RWTH Aachen, (in German).

Jochymaczyk, K., Cabala, J. and Poręba, A: 2006, Application of resistivity imagining to recognition of geological structure in the area of shallow $\mathrm{Zn}-\mathrm{Pb}$ ore bodies (preliminary study). Acta Geodyn. Geomater., 3, 3 (143), 131-138.

Knothe, S.: 1954, The equation profile ultimately educated subsidence trough. Archiwum Górnictwa i Hutnictwa, 1 (1), (in Polish).

Kowalski, A.: 2005, About occurrence of linear discontinuities on the surface. Safety and protection for mining environment, 12, 25-32, WUG, (in Polish).
Kuznetsov, S.V., and Trofimov, V.A.: 2012, Formation of tension and delamination areas in a long excavation's roof. Journal of Mining Science, 48, 5, 789-797.

DOI: $10.1134 / \mathrm{S} 1062739148050036$

Lee, C.F., Zhang, J.M. and Zhang, Y.X.: 1996, Evolution and origin of the ground fissures in Xian, China. Engineering Geology, 43, 1, 45-55.

DOI: 10.1016/0013-7952(95)00088-7

Li, Y., Yang, J. and Hu, X.: 2000, Origin of ground fissures in the Shanxi Graben System, Northern China. Engineering Geology, 55, 4, 267-275, DOI: 10.1016/S0013-7952(99)00082-4

Liu, H., Deng, K., Lei, S. and Bian, Z.:2015, Mechanism of formation of sliding ground fissure in loess hilly areas caused by underground mining. International Journal of Mining Science and Technology, 25, 4, 553-558. DOI: $10.1016 / j . i j m s t .2015 .05 .006$

Pokrzycki, J., Mazak, T. and Zdanowski, A.: 1974, Geological documentation hard coal seam „Chełm". Arch. IG, (in Polish).

Sroka, A.: 2008, Designing coal extraction where the surface is threatened by discontinuous linear deformations. Gospodarka Surowcami Mineralnymi, 24, 2/3, 445-455, (in Polish).

Zhang, D., Qi, X., Yin, G. and Zheng, B.: 2013, Coal and rock fissure evolution and distribution characteristics of multi-seam mining. International Journal of Mining Science and Technology, 23, 6, 835-840.

DOI: 10.1016/j.jimst.2013.10.009 